\title{
ACCIDENT INVESTIGATION NEEDLE STICK INJURY PADA PETUGAS MEDIS DAN NON-MEDIS DI BMC MAYA PADA HOSPITAL TAHUN 2019
}

\author{
Dadan Sungkawa $^{1)}$, Rubi Ginanjar ${ }^{2)}$, dan Andi Asnifatima ${ }^{3)}$
}

\author{
${ }^{1)}$ Program Studi Kesehatan Masyarakat, Fakultas Ilmu Kesehatan, Universitas Ibn Khaldun Bogor. \\ Email: dadan@gmail.com \\ ${ }^{2)}$ Program Studi Kesehatan Masyarakat, Fakultas Ilmu Kesehatan, Universitas Ibn Khaldun Bogor. \\ Email: rubi@uika-bogor.ac.id \\ ${ }^{3)}$ Program Studi Kesehatan Masyarakat, Fakultas Ilmu Kesehatan, Universitas Ibn Khaldun Bogor. \\ Email:asni@uika-bogor.ac.id
}

\begin{abstract}
Abstrak
Needle stick injury (NSI) merupakan suatu robekan di kulit akibat suatu jarum atau benda tajam lainnya seperti pisau bedah, pecahan ampul dan peralatan medis tajam lainnya. Tujuan dari peneltian ini adalah untuk mengetahui penyebab dari terjadinya kejadian kecelakaan tertusuk jarum dan benda tajam (needle stick injury) di BMC Mayapada Hospital. Penelitian ini menggunakan metode pendekatan semi-kuantitatif. Teknik pengambilan sampel menggunakan purposive sampling dengan pertimbangan pekerjaan yang berhubungan dengan NSI, melalui perhitungan rumus slovin didapati sampel sebanyak 100 orang dari jumlah populasi 115 orang. Metode pengumpulan data menggunakan kuesioner dan wawancara mendalam. Metode analisis dengan distribusi frekuensi dan investigasi menggunakan teori loss causation model. Hasil penelitian diketahui 19 kasus, 11 terkena pecahan ampul dan 8 tertusuk jarum. Penyebab lansung yaitu tidak memperhatikan tanda ampul, mematahkan ampul dengan bantalan kertas, mematahkan ampul dengan berdiri, mematahkan ampul dengan menekan pada meja, melakukan recapping dengan 2 tangan, membuka spuit dengan tergesa gesa, kondisi ruangan terbatas dan kondisi pencahayaan yang kurang baik. Sedangkan untuk penyebab dasar yaitu ketidakmampuan sampel dalam mengahadapi kasus emergency, tidak memperhatikan label pada ampul, tubuh pada posisi yang tidak benar, kelelahan saat berkerja, pasien yang kurang koperatif, tidak tersedianya gergaji ampul dan tidak adanya fasilitas ruang pengoplosan obat. Untuk lack of control yaitu kurangnya pelatihan klinis dan universal precaution serta lemahnya pengawasan terhadap para staff yang ada dalam pengimplementasian SOP. Kesimpulannya NSI terbanyak diakibakan oleh unsafe act dan faktor personal yaitu 15 kasus (85\%). Saran kepada perusahaan melakukan pengawasan dengan optimal dan melaksanakan pelatihan berkala.
\end{abstract}

Kata Kunci: Needle Stick Injury, Penyebab Langsung, Penyebab Dasar, Lack of control.

\section{Pendahuluan}

Rumah sakit adalah suatu organisasi yang melalui tenaga medis profesional yang terorganisir serta sarana kedokteran yang permanen menyelenggarakan pelayanan kedokteran, asuhan keperawatan yang berkesinambungan, diagnosis serta pengobatan penyakit yang di derita oleh pasien. Dalam penyelenggaraan pelayanan kedokteran, asuhan keperawatan, serta pengobatan penyakit banyak digunakan alat- 
alat ataupun benda-benda tajam sebagai sarana pendukung. Permasalahan yang muncul dan di hadapi kemudian adalah munculnya kejadian luka tusuk (needle stick injury) pada tenaga medis yang melakukan kegiatan rumah sakit tersebut (Harington, 2013).

Menurut Hinchliff, (1999) dalam kamus keperawatan edisi 17, menyebutkan bahwa needle stick injury adalah istilah yang menggambarkan tentang cedera yang tidak sengaja baik oleh jarum maupun benda tajam medis lainnya yang terkontaminasi darah.

Kejadian luka akibat jarum suntik (needle stick injury) setiap tahunnya terjadi pada sekitar 3 juta orang, sedangkan sebanyak 2 juta dari 35 juta petugas kesehatan di dunia terkena infeksi karena tertusuk jarum suntik (needle stick injury). (WHO, 2011).

Hasil penelitian yang dilakukan oleh American Nurses Association (2010) di Amerika Serikat diperkirakan petugas pelayanan kesehatan di rumah sakit menderita luka tusuk jarum suntik dan luka akibat alat medis tajam lainnya sebanyak 385.000 kasus per tahun atau 1.000 kasus per hari. Tingkat kejadian petugas kesehatan tertusuk jarum suntik di rumah sakit Amerika Serikat tahun 2009 sampai 2011, rata-rata adalah 6,7 \% sampai 9,9\% per 100 tempat tidur.

Di Jepang rata-rata petugas kesehatan tertusuk jarum suntik adalah 6,2\% per 100 tempat tidur, angka kejadian ini lebih banyak terjadi di ruang operasi dan ruang rawat pasien (ICN, 2000).

Di indonesia, dalam kepmenkes Nomor: 1087/MENKES/VII/2010 mencantumkan, penelitian dr. Joseph tahun (2005-2007) mencatat bahwa proporsi luka tertusuk jarum suntik mencapai 38-73\% dari total petugas kesehatan (Rival, 2012).

Rumah Sakit Hasan Sadikin Bandung melaporkan pada tahun 2007 di dapatkan pelaporan 22 orang melaporkan telah tertusuk jarum, tahun 2008 ada 12 orang dan tahun 2009 ada 8 orang (Safetysyringes, 2011).

Data penelitian yang terlaporkan pada kasus needle stick injury untuk wilayah sekitar kota bogor yaitu pada 114 petugas kesehatan di 10 puskesmas DKI Jakarta menunjukan sekitar $84 \%$ di antaranya pernah tertusuk jarum bekas. Penelitian lain yang dilakukan di RSUD Kabupaten Cianjur menyebutkan bahwa jumlah perawat yang mengalami luka tusuk jarum dan benda tajam lainnya cukup tinggi yaitu sebanyak $61,34 \%$ (Hermana, 2009).

Sedangkan untuk data kasus tertusuk jarum dan benda tajam yang ada di rumah sakit PMI Bogor melaporkan tahun 2009 terjadi 6 kasus, 2010 terjadi 4 kasus dan 2011 terjadi 8 kasus. Secara kuantitatif kasus tersebut tidak menunjukan angka kejadian yang signifikan. Hal ini terjadi karena kasus tertusuk jarum dan benda tajam (needle stick injury) yang dilaporkan hanya sedikit, padahal pada kenyataannya banyak perawat yang mengalami kecelakaan kerja tertusuk jarum (seksi K3 RS PMI Bogor, 2011).

Berdasarkan data yang diperoleh dari Komite Pengendalian dan Pencegahan Infeksi (PPI) BMC Mayapada Hospital pada tahun 2017 terjadi 4 kasus luka tertusuk jarum atau benda tajam lainnya yang dimana dialami oleh perawat, petugas laboratorium dan cleaning service. Dimana 2 diantaranya terjadi kasus luka tusuk jarum pada perawat saat menjahit luka dan akan menyuntik pasien, kemudian 1 kasus tertusuk jarum suntik dialami oleh petugas analis laboratorium saat akan mengambil sampel dan 1 kasus terjadi pada petugas cleaning service saat memindahkan limbah medis dari disposal box ke tempat penampungan sementara sebelum diangkut oleh pihak ketiga untuk diolah. Seperti kita ketahui pekerja yang ada di intansi kesehatan berisiko terpapar darah dan cairan tubuh yang 
terinfeksi (bloodborne pathogen) yang dapat menyebabkan infeksi HBV (Hepatitis B Virus), HCV (Hepatitis C Virus) dan HIV (Human Immunodeficiency Virus) melalui sumber infeksi yang diketahui seperti jarum bekas pakai atau benda tajam lainnya.

Berdasarkan latar belakang masalah yang telah dikemukakan, maka dalam penelitian ini penulis merumuskan masalah

\section{Metode}

Jenis penelitian yang digunakan dalam penelitian ini yaitu penelitian investigatif dengan menggunakan teori investigasi Loss Causation Model (Bird dan Germain, 1990) penelitian ini bersifat semi-kuantitatif. Penelitian ini dilakukan di BMC Mayapada Hospital dan dilaksanakan pada bulan Maret 2019.

Populasi dalam penelitian ini dipilih melalui cara Purposive Sampling dimana populasi yang di pilih dianggap mewakili dari keseluruhan pekerjaan yang berhubungan

\section{Hasil}

Gambaran Karakteristik Needle Stick Injury di BMC Mayapad Hospital tahun 2019

Tabel 1 Distribusi Frekuensi Kejadian NSI

\begin{tabular}{lcc}
\hline \multirow{2}{*}{$\begin{array}{c}\text { Accident Needle stick } \\
\text { injury }\end{array}$} & \multicolumn{2}{c}{ Responden } \\
\cline { 2 - 3 } injak Pernah & $\mathrm{N}$ & $\%$ \\
Pernah & 81 & 81.0 \\
\hline Total & 19 & 19.0 \\
\hline
\end{tabular}

Berdasarkan Tabel 1. dapat disimpulkan bahwa responden yang pernah mengalami NSI yaitu sebanyak 19 orang $(19 \%)$. sebagai berikut: "Bagaimana terjadinya accident needle stick injury berdasarkan fakta dan uraian kejadian yang terjadi serta mencari tahu penyebab lasung, penyebab tidak lansung dan penyebab dasar terjadinya needle stick injury pada petugas medis dan non medis di BMC Mayapada Hospital tahun 2019”.

lansung dengan alat yang menyebabkan NSI yaitu perawat rawat inap, analis lab dan cleaning service yang keseluruhannya berjumlah 115 orang. Sampel yang di ambil dalam penelitian ini berjumlah 100 dengan menghitung pada masing masing populasi menggunakan rumus slovin guna mendapatkan data hasil yang homogenitas dan valid.

Tabel 2. Distribusi berdasarkan Aktifitas pekerjaan

\begin{tabular}{|c|c|c|}
\hline \multirow{2}{*}{ Aktifitas Pekerjaan } & \multicolumn{2}{|c|}{ Responden } \\
\hline & $\mathrm{N}$ & $\%$ \\
\hline $\begin{array}{l}\text { Mematahkan ampul/ } \\
\text { vial saat mengambil } \\
\text { obat }\end{array}$ & 11 & 57,9 \\
\hline $\begin{array}{l}\text { Melakukan tindakan } \\
\text { pengambilan sampel } \\
\text { darah }\end{array}$ & 3 & 15,7 \\
\hline $\begin{array}{l}\text { Membuka/Menutup } \\
\text { Jarum dengan teknik } \\
\text { recapping }\end{array}$ & 4 & 21,1 \\
\hline $\begin{array}{l}\text { Tertusuk tidak sengaja } \\
\text { oleh rekan kerja }\end{array}$ & 1 & 5,3 \\
\hline Total & 19 & 100.0 \\
\hline
\end{tabular}

Berdasarkan tabel 2. Aktifitas pekerjaan yang paling banyak mengalami NSI yaitu saat mematahkan ampul yaitu 11 kasus (58\%). 
Tabel 3. Distribusi Frekuensi Berdasarkan Alat Yang Menyebabkan NSI

\begin{tabular}{lcc}
\multicolumn{1}{c}{ Jenis Alat } & \multicolumn{2}{c}{ Responden } \\
\cline { 2 - 3 } & $\mathrm{N}$ & $\%$ \\
\hline $\begin{array}{l}\text { Jarum Suntik } \\
\text { (Hypodermic Needle) }\end{array}$ & 8 & 42,1 \\
$\begin{array}{l}\text { Benda Kaca (ampul, } \\
\text { vial, Botol infus kaca, } \\
\text { pipet kaca) }\end{array}$ & 11 & 57,9 \\
\hline Total & 19 & 100.0 \\
\hline
\end{tabular}

Berdasarkan Tabel 3. jenis alat penyebabnya NSI adalah botol kaca (pecahan ampul) 11 kasus $(63,2 \%)$.

Tabel 4. Distribusi Frekuensi NSI Berdasarkan Jenis Pekerjaan

\begin{tabular}{lcc}
\multirow{2}{*}{$\begin{array}{c}\text { Jenis } \\
\text { Pekerjaan }\end{array}$} & \multicolumn{2}{c}{ Needle stick Injury } \\
\cline { 2 - 3 } & Tidak Pernah & Pernah \\
\hline Perawat & 45 & $\begin{array}{c}16 \\
(84,2 \%)\end{array}$ \\
\hline Analis Lab & 7 & $\begin{array}{c}3 \\
(15,8 \%)\end{array}$ \\
\hline Cleaning & 29 & 0 \\
Service & 81 & 19 \\
\hline Total &
\end{tabular}

Berdasarkan tabel 4 Jenis pekerjaan yang paling banyak mengalami NSI yaitu perawat sebanyak 16 kasus $(84,2 \%)$.
Tabel 5. Distribusi Frekuensi NSI Berdasarkan Usia

\begin{tabular}{lcc}
\multirow{2}{*}{ Usia } & \multicolumn{2}{c}{ Needle stick Injury } \\
\cline { 2 - 3 } & Tidak Pernah & Pernah \\
\hline 17-25 tahun & 8 & $\begin{array}{c}6 \\
(31,6 \%)\end{array}$ \\
\hline 26 -35 tahun & 66 & $\begin{array}{c}13 \\
(68,4 \%)\end{array}$ \\
\hline 36-45 tahun & 7 & 0 \\
\hline Total & 81 & 19 \\
\hline
\end{tabular}

Berdasarkan Tabel 5. usia paling banyak yang mengalami NSI yaitu 26-35 tahun 13 kasus $(68,4 \%)$

Tabel 6. Distribusi Frekuensi NSI Berdasarkan Masa Kerja

\begin{tabular}{rcc}
\hline Masa & \multicolumn{2}{c}{ Needle stick Injury } \\
\cline { 2 - 3 } Kerja & Tidak Pernah & Pernah \\
\hline \multirow{2}{*}{2 tahun } & 3 & $\begin{array}{c}2 \\
(10,6 \%)\end{array}$ \\
\hline & 78 & $\begin{array}{c}17 \\
(89,4 \%)\end{array}$ \\
\hline 2 tahun & & 19 \\
\hline Total & 81 & 2 \\
\hline
\end{tabular}

Berdasarkan Masa kerja yang paling yang paling banyak mengalami NSI yaitu $>2$ tahun sebanyak 17 kasus $(89,6 \%)$.

Tabel 7. Distribusi Frekuensi NSI Berdasarkan Jenis Kelamin

\begin{tabular}{lccc}
\multirow{2}{*}{ Jenis Kelamin } & \multicolumn{2}{c}{ Needle stick Injury } \\
\cline { 2 - 2 } Wanita & Tidak Pernah & Pernah \\
\hline Laki-laki & 32 & 14 \\
& 49 & $(73,7 \%)$ \\
Total & & 5 \\
\hline
\end{tabular}

Berdasarkan Tabel 7 jenis kelamin yang paling banyak mengalami NSI yaitu wanita sebanyak 14 kasus $(73,7 \%)$. 
Tabel 8. Distribusi Frekuensi NSI Berdasarkan Tingkat Pendidikan

\begin{tabular}{lcc}
\hline $\begin{array}{c}\text { Tingkat } \\
\text { Pendidikan }\end{array}$ & \multicolumn{2}{c}{ Needle stick Injury } \\
& Tidak Pernah & Pernah \\
\hline SMA/Sedrajat & 29 & 0 \\
\hline Diploma (D3) & 52 & $\begin{array}{c}17 \\
(89,5 \%)\end{array}$ \\
\hline Sarjana (S1) & 0 & 2 \\
Total & 81 & $10,5 \%)$ \\
\hline
\end{tabular}

Berdasarkan tabel 8. tingkat Pendidikan yang paling banyak mengalami NSI yaitu D3 sebanyak 17 kasus $(89,5 \%)$.

\section{Analisis Investigasi Needle Stick Injury di BMC Maya pada Hospital Tahun 2019}

\section{Penyebab Langsung}

\section{a. Unsafe Action}

Berdasarkan hasil investigasi yang dilakukan dalam penelitian ini terdapat beberapa penyebab lansung berupa tindakan tidak aman yang menyebabkan needle stick injury yaitu diantaranya; Mematahkan ampul tampa memperhatikan tanda pada ampul, mematahkan ampul besar dengan bantalan kertas pada jari, mematahkan ampul dalam keadaan berdiri, mematahkan ampul dengan menekan pada meja, melakukan penutupan spuit atau recapping dengan 2 tangan, kelelahan saat berkerja akibat longshift, kehilangan focus saat setelah melakukan pengoplosan obat, membuka spuit dengan tergesa gesa.

\section{b. Unsafe Condition}

Berdasarkan hasil investigasi yang dilakukan unsafe condition yang memepengaruhi terjadinya NSI yaitu kondisi tempat pengoplosan obat terbatas dan sempit (troley obat) dan kondisi pencahayaan yang kurang baik (redup).

\section{Penyebab Dasar}

\section{a. Personal Factor}

Berdasarkan hasil investigasi dimana yang menjadi faktor personal dalam terjadinya needle stick injury yaitu ketidak mampuan responden dalam mengahadapi kasus emergency dimana responden kehilangan kewaspadaan saat mematahkan ampul, kurangnya kewaspadaan dan perhatian responden saat mematahkan ampul akibat tidak memperhatikan label pada ampul terlebih dahulu sehingga posisi ampul salah saat diapatahkan, kurangnya perhatian responden tehadap bahaya pecahan ampul dengan tidak meposisikan tubuh pada posisi yang benar, kurangnya perhatian responden terhadap kondisi tubuh akibat kelelahan saat berkerja shift malam, ketidak mampuan menghadapi pasien yang tidak koperatif, kurangnya kesigapan responden saat menutup spuit sesaat setelah memasukan obat dari vial obat.

\section{b. Job Factor}

Berdasarkan hasil investigasi yang dilakukan dalam penelitian ini penyebab terjadinya NSI akibat dari penyebab pekerjaan yaitu tidak tersedianya gergaji ampul atau stick pemotong ampul dan tidak adanya ketersedian fasilitas ruang pengoplosan obat injeksi.

\section{Lack Of Control}

Berdasarkan hasil investigasi yang merupakan lack of control dari NSI di BMC Mayapada hospital adalah kurangnya pelatihan yang diadakan dalam pelatihan klinis dan kewaspadaan universal/ universal precaution serta lemahnya pengawasan terhadap aktifitas dan Tindakan pada para staff yang ada dalam pengimpelmentasian SOP. 


\section{Pembahasan}

Berdasarkan Tabel 1. dapat disimpulkan bahwa responden yang pernah mengalami NSI yaitu sebanyak 19 orang (19\%) dari 100 responden dan berdasarkan tabel 2. Aktifitas pekerjaan yang paling banyak mengalami NSI yaitu saat mematahkan ampul yaitu 11 kasus (58\%) dan pada tabel 3 alat yang banyak menyebabkan terjadinya NSI yaitu botol kaca (pecahan ampul) 11 kasus $(63,2 \%)$. Hasil ini tidak sejalan dengan penelitian pada salah satu rumah sakit di Jawa Barat, dimana 74\% responden pernah mengalami cedera benda tajam yang terdiri $32,8 \%$ tertusuk jarum suntik, 24,5\% tergores pecahan ampul dan $3,3 \%$ teriris pisau bedah (Safety syringes, 2011).

Berdasarkan tabel 4 Jenis pekerjaan yang paling banyak mengalami NSI yaitu perawat sebanyak 16 kasus (84,2\%). Hasil penelitian ini sejalan dengan penelitian Mandal (2013) dimana kejadian tertusuk jarum pada perawat terjadi waktu menutup kembali jarum suntik yang sudah di pakai (18\%), tertusuk waktu memasukan kedalam disposal jarum suntik dan saat memindahkan contoh darah ke dalam botol sampel darah untuk pemeriksaan laboratorium oleh petugas lab (16\%).

Berdasarkan Tabel 5. usia paling banyak yang mengalami NSI yaitu 26-35 tahun 13 kasus $(68,4 \%)$. Hal ini sejalan dengan pendapat Suma'mur (1989), yang dikutip oleh Anne Ahira (2009), penelitian dengan tes refleks memberikan kesimpulan bahwa umur mempunyai pengaruh penting terhadap terjadinya kecelakaan, ternyata golongan umur muda mempunyai kecenderungan untuk mendapatkan kecelakaan lebih rendah dibandingkan dengan usia tua karena mereka mempunyai kecepatan reaksi yang lebih tinggi, akan tetapi untuk jenis pekerjaan tertentu sering merupakan golongan tenaga kerja dengan kasus kecelakaan yang tinggi. Hal ini disebabkan oleh kecerobohan dan kelalaian, demikian pula emosi dan motivasi yang merupakan ungkapan jiwa dan emosi seseorang. Kapasitas fisik, seperti penglihatan, pendengaran dan kecepatan reaksi menurun setelah usia 40 tahun, sebaliknya mereka yang ada pada usia ini mungkin lebih berhati-hati, lebih dapat dipercaya dan lebih menyadari akan bahaya dari pada tenaga kerja pada usia muda.

Berdasarkan Masa kerja yang paling yang paling banyak mengalami NSI yaitu $>2$ tahun sebanyak 17 kasus $(89,6 \%)$. Hasil penelitian ini tidak sejalan dengan penelitian yang dilakukan oleh Ermawati B (2015) yang menyatakan bahwa terdapat hubungan antara masa kerja dengan perilaku perawat dalam pencegahan needle stick injury dimana perawat yang memiliki masa kerja lebih lama tidak memilki risiko lebih besar mengalami kecelakaan kerja.

Berdasarkan Tabel 7 jenis kelamin yang paling banyak mengalami NSI yaitu wanita sebanyak 14 kasus $(73,7 \%)$. Hasil penelitian ini tidak sejalan dengan penelitian yang dilakukan oleh (Aditya Sekti Wibowo dkk, 2013) Hubungan Karakteristik Perawat Dengan Penggunaan Sarung Tangan Pada Tindakan Ivasif Di Ruang Rawat Inap RSUD Dr. H. Soewondo Kendal. Dimana hasil analisis bivariat menunjukkan tidak ada hubungan antara jenis kelamin $(\mathrm{p}=0,136)$ dengan penggunaan sarung tangan pada tindakan invasif dan kecelakaan kerja pada perawat.

Berdasarkan tabel 8. tingkat pendidikan yang paling banyak mengalami NSI yaitu D3 sebanyak 17 kasus $(89,5 \%)$. Hal ini sejalan dengan penelitian Ermawati (2014) yang meneliti faktor-faktor yang berhubungan dengan perilaku pencegahan terjadinya needle stick injury di ruangan rawat inap Rumah 
Sakit X Jakarta 2015, diperoleh gambaran pendidikan perawat pelaksana mayoritas D3 Keperawatan yaitu sebanyak $77 \%$.

Berdasarkan hasil investigasi dimana penyebab langsung yang menyebabkan NSI yaitu paling banyak diakibatkan oleh unsafe action sebanyak $85 \%$. Hal ini sejalan dengan Silvia dan Joko hasil penelitian tentang unsafe action di Rumah Sakit Panti Waluya Sawahan Malang menunjukan sebagian besar $(54,5 \%)$ atau 54 orang perawat melakukan unsafe action dan sebagian kecil $(45,5 \%)$ atau 45 orang responden melakukan safe action. Nilai $\mathrm{OR}=1,774$ menunjukan bahwa perawat di RS Panti Waluya yang melakukan unsafe action mempunyai resiko 1,774 kali lebih besar untuk terjadinya kecelakan kerja dibandingkan dengan perawat yang tidak melakukan unsafe action. Adapun unsafe condition yang menjadi penyebab NSI di BMC Mayapada Hospital tidak menjadi penyebab utama akan tetapi dari hasil investigasi dan wawancara, unsafe condition yang ada ternyata mempengaruhi terjadinya NSI. Akan tetapi hasil penelitian ini dengan penelitian Sylvia Puspitasari (2019) yang menyatakan tidak ada hubungannya kejadian NSI pada perawat RSUD leuwiliang dengan unsafe condition dimana dalam penelitiannya nilai $p$ value $=0,301>0,005$ dimana tidak ada hubungan yang signifikan antara kondisi tidak aman dengan kecelakaan kerja tertusuk jarum dan benda tajam lainnya.

Berdasarkan hasil investigasi yang dilakukan pada penelitian ini terdapat penyebab dasar yang memberikan pengaruh cukup besar terhadap NSI yaitu personal factor. Hasil penelitian ini juga sejalan dengan penelitian yang dilakukan oleh Shyeila Sandewa dan Ardian Andhiwijaya (2014) yang menyatakan terdapat hubungan antara keterampilan (faktor personal) dengan risiko kecelakaan kerja pada perawat. Responden dengan keterampilan rendah memiliki risiko 0,237 kali lebih banyak mengalami kecelakaan kerja dibandingkan dengan responden yang memiliki keterampilan baik. Lamanya jam kerja dan kurangnya pengetahuan berkolerasi nyata dengan kejadian tertusuk jarum suntik. (Holla DKK. 2014). Adapun untuk job factor berdasarkan investigasi dalam penelitian ini menunjukan adanya pengaruh terhadap terjadinya NSI. Hal ini sejalan dengan penelitian Aini (2009) dalam penelitiannya yang berjudul Insidensi Luka Tusuk Jarum Pada Perawat Dan Mahasiswa Keperawatan Di RSUP Dr. Sardjito Yogyakarta tahun 2009, dimana seperti ketersediaan fasilitas dan kelengkapan peralatan medis pendukung merupakan factor enabling yang dapat membantu menurunkan kejadian cedera tertusuk jarum suntik seperti sharp box, jarum suntik safety design dll.

Berdasarkan hasil investigasi diketahui terdapat dua akar penyebab dari terjadinya NSI pada petugas medis dan non medis di BMC Mayapada Hospital yaitu kurangnya pelatihan yang diadakan dalam pelatihan klinis dan kewaspadaan universal / universal precaution dan lemahnya pengawasan terhadap implementasi SOP oleh para petugas dalam aktifitas dan tindakan yang dilakukan. Hal ini sejalan dengan hasil penelitian yang dilakukan di RSUD Liunkendage oleh Jefel Endriko Umar (2016) menunjukkan bahwa responden yang memiliki supervisi yang kurang baik yang mengalami kejadian cedera tertusuk jarum suntik sebanyak 80,9\%. Sedangkan jumlah responden yang memiliki supervisi baik yang mengalami kejadian cedera tertusuk jarum suntik sebanyak 63,2\%. Dari data tersebut dapat dilihat responden yang memiliki supervisi yang kurang baik memiliki angka kecelakaan kerja tertusuk jarum suntik yang tinggi, hal tersebut terjadi karena sebagian besar perawat hanya melakukan pekerjaanya secara professional 
dalam hal ini dalam menerapkan SOP dan standar kewaspadaan universal ketika dilihat oleh atasanya atau saat dilakukan supervisi

\section{Kesimpulan}

Dari penelitian ini dapat disimpulkan bahwa kejadian kecelakaan kerja tertusuk jarum suntik atau benda tajam lainnya yaitu sebanyak 19 kasus (19\%). Penyebab langsung yang paling signifikan dalam terjadinya NSI yaitu unsafe action dimana hal ini dipengaruhi oleh penyebab dasar yaitu personal factor yang mana penyebab ini juga memberikan kontribusi besar terhadap

\section{Daftar Pustaka}

[1] Aini, S. N. 2009. Insidensi Luka Tusuk Jarum Pada Perawat Dan Mahasiswa Keperawatan Di RSUP Dr. Sardjito Yogyakarta. Skripsi.

[2] Aziz Alimul Hidayat A. (2007). Metode Penelitian Keperawatan dan Teknik Analisis Data. Jakarta: Salemba Medika

[3] B, Ermawati. (2016). Faktor-faktor Yang Berhubungan Dengan Perilaku Pencegahan Terjadinya Needle Stick Injury Di Ruangan Rawat Inap Rumah Sakit X Jakarta 2015. Jakarta: Skripsi STIK Sint Carolus.

[4] Bird, Frank E. and Germain L.G. Practical Loss Control Leadership. Atlanta USA.1990.

[5] Burhami, Mahfud. (2010) Survey Kecelakaan Kerja Pada Perawat Di RSU Salewangang Kabupaten Maros. Skripsi Fakultas Ilmu Kesehatan Universitas Islam Negeri Alauddin Makassar. Februari 23, 2019

[6] Centers for Disease Control and Prevention. 2013. Stop Sticks: Sharps Injuries. NIOSH. Diakses www.cdc.gov/niosh/stopsticks/sharpinju ries. Diakses: 2 maret 2019 sementara hal sebaliknya dapat terjadi saat tidak dilakukan supervisi.

terjadinya NSI akan tetapi akar permasalahan yang mendasari terjadinya NSI ini yaitu tidak lain lack of control berupa yaitu kurangnya pelatihan yang diadakan dalam pelatihan klinis dan kewaspadaan universal / universal precaution dan lemahnya pengawasan terhadap implementasi SOP oleh para petugas dalam aktifitas dan tindakan yang dilakukan.

[7] Ismail et all, N.H. 2009. Needle Stick Injuriy: A Review Of Twelve Theses Amang HealtCare Personel In Malaysia. Jurnal Of Comuniti Health 2009: Vol 15 Number 1, 47-45.

[8] Kadi, Evana Clarentina. (2016). Analisis Faktor Yang Berhubungan Dengan Needle Stick And Sharps Injuries Pada Perawat Instalasi Rawat Inap, Gawat Darurat, Dan Bedah Di RS PMI Bogor Tahun 2016. Depok: Tesis Universitas Indonesia.

[9] Levy, B. S. \& Wegman D. H. (2000) Occupational Hygiene. Occupational health: Recognizing and Preventing Work related disease and injury. $4^{\text {th }}$ ed., 161-180, Philadelphia, PA: Lippincott Williams and Wilkins.

[10] Mandal, J. (2013) NSI: A major occupational hazards among the health care workers in Nepal. International Journal of Occupational Safety and Health, 3(1), $22-25$.

[11] Martha \& Kresno. (2016). Metodologi Penelitian Kualititatif Untuk Bidang Kesehatan. Jakarta: PT. Raja Grafindo Persada 
[12] National Institute for Occupational Health and Safety (NIOSH). Preventing Needle stick Injuries in Health Care Settings. November, 1999. Publication NR. 2000-108 diakses: Februari 23, 2019

https://www.who.int/occupational_healt h/activities/2ic nneed.pdf

[13] Notoadmodjo, Soekidjo. (2010). Metodologi Penelitian Kesehatan. Jakarta: Rineka Cipta. OSHA. Accident Investigation. Retrieved March 3, 2019 from

http:/www.osha.gov/SLTC/smallbusines s/sec6.html.

[14] Puspitasari, Apriastuti. (2011). Analisis Human Error Pada Kejadian Kecelakaan di Direktorat Logistik \& Ekspor Plant Narogong PT Holcim Indonessia, TBK Tahun 2010. Skripsi Fakultas Kesehatan Masyarakat Universitas Indonesia. Februari 23, 2019.

[15] Royal College of nursing (2009) Needle stick Injuries; point of Prevention. Accessed.from:

https://www2.rcn.org.uk/data/assets/p df_file/0007/230884/003313.pdf

(Accessed 23-02-2019).
[16] Suma'mur. Keselamatan Kerjadan Pencegahan Kecelakaan. Jakarta: Gunung Agung. 2001.

[17] Umar, JE, Doda, VD \& Kekenusa, JS. (2017). Faktor-faktor Yang Berhubungan Dengan Kejadian Cedera Tertusuk Jarum Suntik Pada Perawat Di Rumah Sakit Liunkendage Tahuna. Jurnal Pascasarjana Ilmu Kesehatan Masyarakat, Vol 2, No 42017.

[18] Undang-Undang Nomor 44 Tahun 2009 tentang Rumah Sakit

[19] Wiegmann \& Shappel. (2003). A Human Error Approach to Aviation Accident: Analysis the Human Factors Analysis and Classification System. Aldershot: Ashgate Publising Limited. Februari 23, 2019.

[20] World Health Organization. (2013) Global Health Observatory (GHO) data. Diakses: February 16, 2019. https://www.who.int/gho/road_safety/en I

[21] World Health Organization. (2019). Gender, equaty and human rights. Januari 29, 2019 